\title{
THE CONSTRUCTION AND EVALUATION OF A SCALE OF EMPLOYEE EMPOWERMENT
}

\author{
VANESSA J CLOETE \\ F CROUS \\ J M SCHEPERS \\ Programme in Industrial Psychology \\ Department of Human Resource Management \\ Rand Afrikaans University
}

\begin{abstract}
The purpose of this study was to construct and evaluate a scale of employee empowerment that may benefit organisational transformation. An Employee Empowerment Questionnaire consisting of 90 items was developed and administered to 164 respondents within a large metropolitan council. The study indicated that the Employee Empowerment Questionnaire is highly reliable $(\mathrm{rxx}=0,982)$ and sensitive to group differences.
\end{abstract}

\section{OPSOMMING}

Die doel van die studie was om ' $n$ skaal van werknemerbemagtiging vir organisasie-transformasiedoeleindes te konstrueer en te evalueer. 'n Werknemerbemagtigingsvraelys, bestaande uit 90 items is ontwikkel en toegepas op 164 respondente in ' $n$ plaaslike owerheid. Die studie het aangedui dat die Werknemerbemagtigingsvraelys hoogs betroubaar $(\mathrm{rxx}=0,982)$ en sensitief vir groepsverskille is.

One of the critical issues confronting managers in the process of transforming organisations, is employee empowerment (Robbins, 2001). Empowerment is an organisational strategy that gives workers greater responsibility for decisionmaking and increased involvement in controlling work processes (Schreuder \& Theron, 1997). The empowerment trend emerged as organisations recognised their employees' capacity to improve and enhance organisational performance through being informed and involved; through the recognition of their skills and experience and being encouraged to be creative, innovative and to take risks (Cooks, 1993; Lepree, 1995; Losey, 1995). As such, empowerment has a democratising function as it addresses the redistribution of authority and accountability in the organisation. Most often it entails the granting of greater decision-making power to front-line employees which enables them to improve the way work is done or to customise the process for customers (Heil, Bennis \& Stephens, 2000).

Empowerment is both difficult to define and measure (Scott \& Jaffe, 1992) and even more so to implement (Semler, 1994). As far as the definition of empowerment is concerned, Bekker and Crous (1998) addressed the understanding of empowerment by clarifying the role and contribution of empowerment in organisations and how empowerment differs from concepts such as employee involvement and participation.

In their search for a definition of empowerment, Bekker and Crous (1998) identified three main streams of thinking. Firstly, they highlighted an organisational empowerment perspective (an 'objective' dimension), comprising aspects such as team-work, information sharing and decision making on an organisational level. Secondly, they identified definitions focusing on the individual empowerment perspective (a 'subjective' dimension) with discussions relating to aspects such as motivation, followership, organisational commitment, locus of control and entitlement. The third stream of thinking incorporated a training and development perspective (a 'competence' dimension). As a result, empowerment is seen to be multi-dimensional

Requests for copies should be addresses to: VJ Cloete, Programme in Industrial Psychology, Department of Human Resource Management, RAU, PO Box 524, Auckland Park, 2006 in nature, achieved through the interaction of the aforementioned dimensions - organisational, individual and development competence - which manifests at individual, intra and inter-group levels (Cook, 1993).

As regards the implementation of empowerment, Scott and Jaffe (1992) were of the opinion that emphasis should be placed on the subjective dimension of empowerment, and as such the level of empowerment as perceived by employees should therefore be assessed prior to taking any action for implementation. Shared general employee perceptions can be expressed as the empowerment climate (Saal \& Knight, 1988). For a comprehensive definition on climate, Tustin (1993) referred to Woodman and King (1997, p. 818) who stated the following: "Climate is reality-based and thus capable of being shared in the sense that observers or participants may agree upon the climate of an organisation or group, although this consensus may be constrained by individual differences in perception". Barnes (1990) referred to the view of Payne and Mansefield (1973) who were of the opinion that the concept of climate may provide a conceptual link between organisational and individual dimensions.

As regards the structure of the climate for empowerment as construct, Scott and Jaffe (1992) mentioned that in working with organisations to improve the climate of empowerment, the following qualities were listed repeatedly: clarity of purpose, morale, fairness, recognition, team-work, participation, communication and a healthy environment.

The context of the present study: A local government environment.

The mindset within the traditional bureaucracy, according to Brown and Brown (1994), is almost entirely foreign to ideas of empowerment. Empowerment rejects a mindset of highly controlled, scarcely involved, authoritarian culture of rules and procedures, and the presumption that "management knows best". These mindsets may cripple an organisation such as a local government that has indicated a movement away from bureaucracy (traditionally associated with government institutions) toward becoming a participative and customerdriven organisation (Egoli 2002 document, 2000). 
With the implementation of the Unicity model of local government within the Greater Johannesburg metropole, whereby five independent councils will be merged into a single local authority, it has become increasingly important that local government employees be empowered to make the necessary decisions, increase service delivery and add value to the organisation (Egoli 2002 document, 2000).

At first, local government management was of the opinion that it would not be possible for a local government to empower its employees. As motivation, they stated that government institutions such as local authorities and the Unicity, which supply statutory services, require customerinterfacing staff be consistent in the application of specified rules. The need for such rules is fuelled by the fear that exercising discretion in the provision of public services can be risky and may lead to anomalies. As a result, rules drift as initiatives become embedded as new practices. According to Eccles (1993) such procedural requirements inhibit empowerment in practice, but this should not discourage management, since employees must then be empowered to carry out the closely specified tasks with maximum responsiveness to given signals.

For the envisaged Unicity to be successful, management must enthuse employees to adhere to a mission and set of strategies which address the needs and provide valuefor-money services to the community they serve, which may lead to empowerment. Every employee requires a clear grasp of the mission of the organisation and an understanding where his or her job fits into the broader organisational strategy (Potter, 1994).

According to Eccles (1993) empowerment is effective when a powerful management is so confident of its grip on the organisation, that it can devolve power in order to hasten the implementation of its overall policies. Individuals need to be valued for who they are, and not merely as instruments. Employees at every level need to act decisively and provide their energies, initiatives and intelligence to benefit of the organisation (Nixon, 1994).

It is perhaps within this context that the broad motives for forming a Unicity need to be outlined. The driving force behind the move to a Unicity was informed by a broad vision of a city capable of meeting its inhabitants' (customers) basic needs, growing the economy, creating jobs and becoming more competitive.

In order to achieve the objectives of the Unicity model, local government needs to create a climate conducive to empowerment. The first step in such a process would be to determine local government employees' perceptions of empowerment, in order to identify possible areas of concern. These need to be addressed so as to ensure successful organisational transformation (Scott \& Jaffe, 1992). The measuring of empowerment perceptions can assist in applying the correct intervention to lead an organisation, such as local government, through a transitional period.

The primary purpose of this study was the construction and evaluation of an empowerment scale. Since the possibility of sub-climates of empowerment exists (Payne, 1995), a secondary aim was to compare groups with different biographical backgrounds in respect of age, gender, language, length of service, qualifications and remuneration. In this regard the following research hypotheses were formulated:

\section{Hypothesis 1}

Female employees will perceive themselves as being less empowered than their male counterparts.

The rationale for this hypothesis rests on the assumption that males are still in advantaged positions in local government organisations, even though this probably occurs to a lesser extent today.

\section{Hypothesis 2}

Older employees will perceive themselves as being less empowered than their younger counterparts.

The rationale for this hypothesis rests on the assumption that older employees tend to stick to tried and trusted ideas. Furthermore, younger workers have not been exposed to the same restrictive conditions the older workers experienced in the past.

\section{Hypothesis 3}

Africans or Black employees will perceive themselves as being more empowered than white or Asian employees.

The rationale for this hypothesis rests on the assumption that for decades, South Africa was characterised by racial inequality as far as empowerment is concerned. However, due to the political changes and new legislation with regard to affirmative action South Africa can no longer be characterised by racial inequality.

\section{Hypothesis 4}

Employees with a longer service in local authorities will perceive themselves as being less empowered than employees with shorter service records.

The rationale for this hypothesis rests on the assumption that employees with a greater length of service experienced the restrictive conditions which held under the previous regime.

\section{Hypothesis 5}

Employees with formal tertiary qualifications will perceive themselves as being more empowered than employees with matric qualifications or lower.

The rationale for this hypothesis rests on the assumption that employees with higher academic qualifications are more likely to focus their time and efforts on developing their intellectual potential in the workplace than those with lesser qualifications.

\section{Hypothesis 6}

Employees earning a high salary will perceive themselves as being more empowered than employees earning a lower salary.

The rationale for this hypothesis rests on the findings of Exley (1993, p.5), namely that employees higher up in the organisation have greater power to effect change than do employees lower down in the hierarchy.

\section{METHOD}

\section{Sample}

The organisation from which the sample was drawn is a local authority. The organisation consists of a metropolitan council and four metropolitan local councils, which are in the process of merging into a single local authority, to be known as the Unicity.

The test sample consisted of 164 randomly selected employees. The sample was drawn from all functions and cultural groups within the organisation. It consisted of 75 males and 74 females and 15 of unknown gender, the majority of the respondents were in the 31 - 40 year age group and have been in service for more than 10 years. The group comprised both genders and 7,39\% possessed a qualification of Standard 10 or higher, with $41,46 \%$ Afrikaans speaking, $22,56 \%$ English speaking and 25\% other mother tongues. The majority of the group earned between R 4 266-00 and R 8 034-00 per month. 
TABLE 1

BIOGRAPHICAL INFORMATION OF RESPONDENTS

\begin{tabular}{|c|c|c|}
\hline & $\mathbf{N}$ & Pecentage \\
\hline \multicolumn{3}{|l|}{ 1. GENDER } \\
\hline Male & 75 & $45,73 \%$ \\
\hline Female & 74 & $45,12 \%$ \\
\hline Unknown & 15 & $9,14 \%$ \\
\hline \multicolumn{3}{|l|}{ 2. AGE } \\
\hline$<30$ & 38 & $23,17 \%$ \\
\hline $31-40$ & 54 & $32,92 \%$ \\
\hline $40+$ & 53 & $32,31 \%$ \\
\hline Unknown & 19 & $11,58 \%$ \\
\hline \multicolumn{3}{|l|}{ 3. LENGTH OF SERVICE } \\
\hline$<5$ & 36 & $21,95 \%$ \\
\hline $5-10$ & 42 & $25,61 \%$ \\
\hline$>10$ & 70 & $42,68 \%$ \\
\hline Unknown & 16 & $9,75 \%$ \\
\hline \multicolumn{3}{|l|}{ 4. QUALIFICATIONS } \\
\hline Std6 - std 8 & 28 & $17,07 \%$ \\
\hline Matric & 61 & $37,19 \%$ \\
\hline Diploma & 26 & $15,85 \%$ \\
\hline $\begin{array}{l}\text { Degree, Honours or } \\
\text { Master's }\end{array}$ & 35 & $21,34 \%$ \\
\hline Unknown & 14 & $8,53 \%$ \\
\hline \multicolumn{3}{|l|}{ 5. MOTHER TONGUE } \\
\hline Afrikaans & 68 & $41,46 \%$ \\
\hline English & 37 & $22,56 \%$ \\
\hline Other & 41 & $25,00 \%$ \\
\hline Unknown & 18 & $10,97 \%$ \\
\hline \multicolumn{3}{|l|}{ 6. REMUNERATION } \\
\hline$<\mathrm{R} 4230$ & 49 & $29,87 \%$ \\
\hline R4266 - R8034 & 61 & $37,19 \%$ \\
\hline$>$ R9155 & 36 & $21,95 \%$ \\
\hline Unknown & 18 & $10,97 \%$ \\
\hline
\end{tabular}

Note $\mathrm{N}=164$

\section{Measuring instruments}

Scott and Jaffe (1992) developed a questionnaire consisting of 35 items based on the following qualities or dimensions: Clarity of purpose, morale, fairness, recognition, teamwork, participation, communication and healthy environment. These qualities were used as a source during the compilation of the Employee Empowerment Questionnaire (EEQ). Since the metric properties of Scott and Jaffe's instrument were inadequate, a more comprehensive questionnaire was developed, incorporating each of the abovementioned qualities.

For the purpose of this study, 90 items were formulated. The questionnaire was specifically designed to determine employees' perception of empowerment. Each item in the questionnaire uses a seven-point response scale - a format which is appropriate, in that it allows for a wide range of responses, ranging from very unfavourable to extremely favourable. All the questions and instructions were presented in both English and Afrikaans. The Employee Empowerment Questionnaire consists of three sections: an instruction section, a biographical information section and the questionnaire as such.

\section{Procedure}

Three hundred copies of the EEQ were sent to pre-selected individuals who assisted with the administration. The questionnaires were completed by the research participants at a specific location and time. One hundred and sixty four completed questionnaires were returned, yielding a response rate of $54,6 \%$. The outstanding questionnaires were not returned. This can be attributed to the fact that the organisation is currently experiencing a transformation period and that the employees perceived the questionnaire as an evaluation of their ability which might influence their position in the new organisation.

\section{RESULTS}

In order to determine the factor structure of the Employee Empowerment Questionnaire (EEQ) the 90 items were intercorrelated and subjected to a principal factor analysis: In order to determine the dimensionality of the vector space of items, the items were intercorrelated and the eigenvalues of the unreduced intercorrelation matrix calculated. It was found that 19 eigenvalues were greater than unity, accordingly 19 factors were postulated (Kaiser, 1961). The 19 factors were extracted and rotated to simple structure by means of the Direct Oblimin rotation. The intercorrelation matrix, eigenvalues and factor matrix are not reproduced here because of limited space.

TABLE 2

MATRIX OF INTERCORRELATIONS OF THE SUBTESTS OF THE EEQ

\begin{tabular}{|c|c|c|c|c|c|c|c|c|c|c|c|c|c|c|c|c|c|c|c|}
\hline $\begin{array}{l}\text { Sub- } \\
\text { test }\end{array}$ & $\begin{array}{l}\text { Sub- } \\
\text { test1 }\end{array}$ & $\begin{array}{l}\text { Sub- } \\
\text { test2 }\end{array}$ & $\begin{array}{l}\text { Sub- } \\
\text { test3 }\end{array}$ & $\begin{array}{l}\text { Sub- } \\
\text { test4 }\end{array}$ & $\begin{array}{l}\text { Sub- } \\
\text { test5 }\end{array}$ & $\begin{array}{l}\text { Sub- } \\
\text { test6 }\end{array}$ & $\begin{array}{l}\text { Sub- } \\
\text { test7 }\end{array}$ & $\begin{array}{l}\text { Sub- } \\
\text { test8 }\end{array}$ & $\begin{array}{l}\text { Sub- } \\
\text { test9 }\end{array}$ & $\begin{array}{l}\text { Sub- } \\
\text { test10 }\end{array}$ & $\begin{array}{l}\text { Sub- } \\
\text { test11 }\end{array}$ & $\begin{array}{l}\text { Sub- } \\
\text { test12 }\end{array}$ & $\begin{array}{l}\text { Sub- } \\
\text { test13 }\end{array}$ & $\begin{array}{l}\text { Sub- } \\
\text { test14 }\end{array}$ & $\begin{array}{l}\text { Sub- } \\
\text { test15 }\end{array}$ & $\begin{array}{l}\text { Sub- } \\
\text { test16 }\end{array}$ & $\begin{array}{l}\text { Sub- } \\
\text { test17 }\end{array}$ & $\begin{array}{l}\text { Sub- } \\
\text { test18 }\end{array}$ & $\begin{array}{l}\text { Sub- } \\
\text { test19 }\end{array}$ \\
\hline 1 & 1.000 & 0,759 & 0,696 & 0,730 & 0,814 & 0,653 & 0,658 & 0,631 & 0,343 & 0,255 & 0,625 & 0,730 & 0,091 & 0,111 & 0,313 & $-0,026$ & 0,460 & $-0,066$ & 0,599 \\
\hline 2 & 0,759 & 1.000 & 0,755 & 0,725 & 0,725 & 0,643 & 0,624 & 0,698 & 0,410 & 0,223 & 0,588 & 0,694 & 0,115 & 0,193 & 0,212 & $-0,032$ & 0,470 & $-0,016$ & 0,511 \\
\hline 3 & 0,696 & 0,755 & 1.000 & 0,680 & 0,715 & 0,722 & 0,651 & 0,621 & 0,373 & 0,178 & 0,592 & 0,687 & 0,082 & 0,171 & 0,202 & $-0,058$ & 0,642 & $-0,077$ & 0,483 \\
\hline 4 & 0,730 & 0,725 & 0,680 & 1.000 & 0,701 & 0,659 & 0,697 & 0,646 & 0,384 & 0,241 & 0,620 & 0,670 & 0,017 & 0,038 & 0,242 & 0,015 & 0,413 & 0,001 & 0,416 \\
\hline 5 & 0,814 & 0,725 & 0,715 & 0,701 & 1.000 & 0,711 & 0,690 & 0,622 & 0,372 & 0,340 & 0,625 & 0,775 & 0,150 & 0,075 & 0,237 & 0,005 & 0,427 & 0,010 & 0,532 \\
\hline 6 & 0,653 & 0,643 & 0,722 & 0,659 & 0,711 & 1.000 & 0,621 & 0,477 & 0,293 & 0,167 & 0,637 & 0,693 & $-0,065$ & 0,076 & 0,284 & $-0,028$ & 0,447 & $-0,058$ & 0,424 \\
\hline 7 & 0,658 & 0,624 & 0,651 & 0,697 & 0,690 & 0,621 & 1.000 & 0,480 & 0,276 & 0,159 & 0,492 & 0,661 & $-0,113$ & 0,133 & 0,214 & 0,053 & 0,464 & 0,059 & 0,422 \\
\hline 8 & 0,631 & 0,698 & 0,621 & 0,646 & 0,622 & 0,477 & 0,480 & 1.000 & 0,471 & 0,208 & 0,521 & 0,547 & 0,233 & 0,118 & 0,172 & 0,035 & 0,377 & $-0,135$ & 0,418 \\
\hline 9 & 0,343 & 0,410 & 0,373 & 0,384 & 0,372 & 0,293 & 0,276 & 0,471 & 1.000 & 0,279 & 0,299 & 0,363 & 0,170 & 0,069 & 0,094 & 0,054 & 0,244 & $-0,161$ & 0,247 \\
\hline 10 & 0,255 & 0,223 & 0,178 & 0,241 & 0,340 & 0,167 & 0,159 & 0,208 & 0,279 & 1.000 & 0,248 & 0,216 & 0,140 & 0,145 & 0,017 & $-0,144$ & 0,111 & 0,083 & 0,146 \\
\hline 11 & 0,625 & 0,588 & 0,592 & 0,620 & 0,625 & 0,637 & 0,492 & 0,521 & 0,299 & 0,248 & 1.000 & 0,522 & $-0,064$ & 0,032 & 0,197 & $-0,046$ & 0,289 & $-0,065$ & 0,330 \\
\hline 12 & 0,730 & 0,694 & 0,687 & 0,670 & 0,775 & 0,693 & 0,661 & 0,547 & 0,363 & 0,216 & 0,522 & 1.000 & 0,010 & 0,065 & 0,271 & $-0,032$ & 0,466 & $-0,032$ & 0,512 \\
\hline 13 & 0,091 & 0,115 & 0,082 & 0,017 & 0,150 & $-0,065$ & $-0,113$ & 0,233 & 0,170 & 0,140 & $-0,064$ & 0,010 & 1.000 & 0,008 & $-0,011$ & 0,125 & 0,057 & $-0,006$ & 0,091 \\
\hline 14 & 0,111 & 0,193 & 0,171 & 0,038 & 0,075 & 0,076 & 0,133 & 0,118 & 0,069 & 0,145 & 0,032 & 0,065 & 0,008 & 1.000 & $-0,032$ & 0,066 & 0,124 & $-0,001$ & 0,002 \\
\hline 15 & 0,313 & 0,212 & 0,202 & 0,242 & 0,237 & 0,284 & 0,214 & 0,172 & 0,094 & 0,017 & 0,197 & 0,271 & $-0,011$ & $-0,032$ & 1.000 & $-0,020$ & 0,061 & $-0,096$ & 0,154 \\
\hline 16 & $-0,026$ & $-0,032$ & $-0,058$ & 0,015 & 0,005 & $-0,028$ & 0,053 & 0,035 & 0,054 & $-0,144$ & $-0,046$ & $-0,032$ & 0,125 & 0,066 & $-0,020$ & 1.000 & 0,070 & 0,082 & 0,065 \\
\hline 17 & 0,460 & 0,470 & 0,642 & 0,413 & 0,427 & 0,447 & 0,464 & 0,377 & 0,244 & 0,111 & 0,289 & 0,466 & 0,057 & 0,124 & 0,061 & 0,070 & 1.000 & 0,032 & 0,322 \\
\hline 18 & $-0,066$ & $-0,016$ & $-0,077$ & 0,001 & 0,010 & $-0,058$ & 0,059 & $-0,135$ & $-0,161$ & 0,083 & $-0,065$ & $-0,032$ & $-0,006$ & $-0,001$ & $-0,096$ & 0,082 & 0,032 & 1.000 & 0,030 \\
\hline 19 & 0,599 & 0,511 & 0,483 & 0,416 & 0,532 & 0,424 & 0,422 & 0,418 & 0,247 & 0,146 & 0,330 & 0,512 & 0,091 & 0,002 & 0,154 & 0,065 & 0,322 & 0,030 & 1.000 \\
\hline
\end{tabular}


To counteract the effect of differential skewness of items, subscores were computed in respect of each of the factors by adding all the items with high loadings on a factor. The subscores were then intercorrelated and subjected to factor analysis. The matrix of intercorrelations of the subscores is given in Table 2, and the eigenvalues of this matrix in Table 3.

TABLE 3

EIGENVALUES OF THE SUBTESTS OF THE EEQ

\begin{tabular}{cc}
\hline ROOT & EIGENVALUE \\
\hline 1 & 7,991 \\
2 & $\mathbf{1 , 3 8 2}$ \\
3 & $\mathbf{1}, 226$ \\
4 & $\mathbf{1 , 1 4 9}$ \\
5 & 1,052 \\
6 & 0,897 \\
7 & 0,821 \\
8 & 0,692 \\
9 & 0,673 \\
10 & 0,600 \\
11 & 0,480 \\
12 & 0,442 \\
13 & 0,316 \\
14 & 0,292 \\
15 & 0,259 \\
16 & 0,222 \\
17 & 0,207 \\
18 & 0,173 \\
19 & 0,124 \\
\hline TRACE & 19,000
\end{tabular}

From an inspection of Table 2 it is clear that most of the subtests correlated highly with one another, however, there are also a number that correlated lowly with the rest. This probably implies a single factor structure, with some poor items included in the set.

Table 3 indicates five eigenvalues greater than unity, suggesting five factors. Accordingly, five factors were extracted and rotated to simple structure by means of a Direct Oblimin rotation. The rotated factor matrix is given in Table 4.

TABLE 4

ROTATED FACTOR MATRIX OF THE SUBTESTS OF THE EEQ

\begin{tabular}{lcccccc}
\hline & Factor I & Factor II & Factor III & Factor IV & Factor $\mathbf{V}$ & $\mathbf{h}^{2} \mathbf{j}$ \\
\hline Subtest1 & $\underline{0,891}$ & 0,053 & 0,101 & 0,017 & 0,042 & 0,807 \\
Subtest2 & $\underline{0,728}$ & 0,018 & 0,119 & $-0,090$ & $-0,204$ & 0,747 \\
Subtest3 & $\underline{0,635}$ & $-0,089$ & $-0,050$ & $-0,155$ & $-\underline{-0,488}$ & 0,866 \\
Subtest4 & $\underline{0,795}$ & 0,054 & $-0,007$ & $-0,032$ & $-0,059$ & 0,693 \\
Subtest5 & $\underline{\underline{0,889}}$ & 0,149 & 0,124 & 0,120 & 0,033 & 0,836 \\
Subtest6 & $\underline{0,775}$ & $-0,013$ & $-0,213$ & $-0,050$ & $-0,124$ & 0,695 \\
Subtest7 & $\underline{0,764}$ & $-0,053$ & $-0,156$ & 0,170 & $-0,170$ & 0,665 \\
Subtest8 & $\underline{0,557}$ & 0,029 & $\underline{0,337}$ & $-0,295$ & $-0,131$ & 0,689 \\
Subtest9 & 0,264 & 0,156 & 0,253 & $-0,252$ & $-0,138$ & 0,335 \\
Subtest10 & 0,109 & $\underline{0,842}$ & 0,093 & 0,176 & $-0,090$ & 0,779 \\
Subtest11 & $\underline{0,668}$ & 0,139 & $-0,135$ & $-0,137$ & $-0,012$ & 0,552 \\
Subtest12 & $\underline{0,823}$ & 0,014 & $-0,023$ & 0,046 & $-0,056$ & 0,699 \\
Subtest13 & $-0,049$ & 0,072 & $\underline{0,598}$ & $-0,052$ & 0,004 & 0,358 \\
Subtest14 & $-0,026$ & 0,063 & 0,012 & $-0,000$ & $-0,282$ & 0,085 \\
Subtest15 & $\underline{0,367}$ & $-0,028$ & $-0,045$ & $-0,082$ & 0,176 & 0,143 \\
Subtest16 & 0,007 & $-0,195$ & 0,219 & 0,114 & $-0,026$ & 0,108 \\
Subtest17 & $\underline{0,354}$ & $-0,146$ & 0,006 & 0,052 & $-\underline{-0,512}$ & 0,502 \\
Subtest18 & 0,037 & 0,058 & $-0,009$ & $\underline{0,491}$ & $-0,012$ & 0,232 \\
Subtest19 & $\underline{0,600}$ & $-0,034$ & 0,176 & 0,123 & 0,026 & 0,389 \\
\hline
\end{tabular}

From an inspection of Table 4 it is clear that only the first factor is properly determined, with 11 high loadings. The other factors are all poorly determined. It is therefore clear that only one factor underlies the intercorrelation matrix. Next, a single scale was formed by including all the items with high loadings on the first factor. This scale, with 84 items, was subjected to item analysis. The item statistics are given in Table 5 .
TABLE 5

ITEM STATISTICS OF SCALE 1 OF THE EEQ

\begin{tabular}{|c|c|c|c|c|}
\hline Item & $\mathbf{r}_{\mathrm{gx}} \mathbf{s}_{\mathrm{g}}$ & $r_{g x}$ & $\mathbf{s}_{\mathrm{g}}$ & $\bar{X}_{\mathrm{g}}$ \\
\hline B1 & 0,908 & 0,614 & 1,480 & 3,278 \\
\hline B2 & 1,030 & 0,644 & 1,599 & 4,059 \\
\hline B3 & 0,988 & 0,607 & 1,626 & 4,491 \\
\hline B4 & 1,085 & 0,699 & 1,551 & 3,473 \\
\hline B5 & 1,007 & 0,600 & 1,678 & 4,219 \\
\hline B6 & 0,991 & 0,641 & 1,546 & 3,568 \\
\hline B7 & 0,864 & 0,592 & 1,460 & 3,278 \\
\hline B8 & 1,176 & 0,657 & 1,792 & 4,166 \\
\hline B9 & 0,971 & 0,596 & 1,630 & 3,763 \\
\hline B10 & 1,210 & 0,673 & 1,798 & 3,325 \\
\hline B11 & 1,050 & 0,710 & 1,479 & 2,568 \\
\hline B12 & 0,911 & 0,608 & 1,497 & 3,213 \\
\hline B13 & 0,986 & 0,630 & 1,565 & 3,296 \\
\hline B14 & 0,871 & 0,632 & 1,377 & 3,041 \\
\hline B15 & 0,961 & 0,665 & 1,446 & 2,568 \\
\hline B16 & 1,066 & 0,713 & 1,494 & 2,670 \\
\hline B17 & 0,996 & 0,571 & 1,743 & 4,095 \\
\hline B18 & 0,852 & 0,559 & 1,523 & 3,669 \\
\hline B19 & 1,122 & 0,722 & 1,555 & 3,692 \\
\hline B20 & 0,914 & 0,619 & 1,476 & 3,503 \\
\hline B21 & 0,956 & 0,610 & 1,568 & 3,219 \\
\hline B22 & 0,970 & 0,664 & 1,460 & 2,746 \\
\hline B23 & 0,740 & 0,526 & 1,406 & 3,107 \\
\hline B24 & 1,032 & 0,669 & 1,542 & 3,166 \\
\hline B25 & 1,141 & 0,691 & 1,650 & 3,059 \\
\hline B26 & 1,082 & 0,709 & 1,527 & 3,118 \\
\hline B27 & 0,937 & 0,681 & 1,376 & 3,893 \\
\hline B28 & 0,832 & 0,576 & 1,444 & 3,609 \\
\hline B29 & 0,821 & 0,557 & 1,474 & 3,888 \\
\hline B31 & 1,107 & 0,712 & 1,555 & 3,154 \\
\hline B33 & 1,165 & 0,744 & 1,566 & 3,450 \\
\hline B34 & 1,038 & 0,592 & 1,753 & 3,533 \\
\hline B35 & 0,652 & 0,436 & 1,495 & 5,148 \\
\hline B36 & 0,994 & 0,654 & 1,520 & 3,722 \\
\hline B38 & 1,133 & 0,713 & 1,590 & 3,888 \\
\hline B40 & 0,999 & 0,627 & 1,592 & 4,562 \\
\hline B41 & 0,965 & 0,629 & 1,534 & 3,929 \\
\hline B42 & 0,898 & 0,577 & 1,556 & 4,053 \\
\hline B43 & 0,977 & 0,627 & 1,558 & 2,976 \\
\hline B44 & 1,129 & 0,741 & 1,524 & 3,538 \\
\hline B45 & 1,128 & 0,720 & 1,566 & 3,515 \\
\hline B46 & 1,040 & 0,693 & 1,500 & 3,462 \\
\hline B47 & 0,997 & 0,635 & 1,570 & 3,533 \\
\hline B48 & 0,570 & 0,334 & 1,709 & 3,970 \\
\hline B49 & 0,928 & 0,626 & 1,482 & 3,586 \\
\hline B50 & 1,007 & 0,745 & 1,351 & 3,142 \\
\hline B51 & 0,417 & 0,262 & 1,595 & 3,249 \\
\hline B52 & 0,693 & 0,467 & 1,486 & 3,675 \\
\hline B54 & 1,000 & 0,648 & 1,542 & 3,302 \\
\hline B55 & 0,969 & 0,605 & 1,600 & 3,609 \\
\hline B56 & 1,048 & 0,746 & 1,405 & 3,373 \\
\hline B57 & 0,785 & 0,594 & 1,322 & 2,550 \\
\hline B58 & 1,001 & 0,610 & 1,641 & 3,284 \\
\hline B59 & 0,736 & 0,528 & 1,395 & 3,781 \\
\hline B60 & 0,995 & 0,668 & 1,490 & 2,929 \\
\hline B61 & 0,984 & 0,626 & 1,572 & 3,420 \\
\hline B 62 & 0,963 & 0,715 & 1,346 & 3,124 \\
\hline B63 & 0,785 & 0,580 & 1,354 & 2,154 \\
\hline B64 & 1,158 & 0,720 & 1,607 & 3,462 \\
\hline B65 & 0,950 & 0,627 & 1,516 & 3,391 \\
\hline B66 & 0,874 & 0,627 & 1,393 & 3,657 \\
\hline B67 & 0,972 & 0,657 & 1,480 & 2,621 \\
\hline B68 & 0,996 & 0,647 & 1,539 & 2,846 \\
\hline B70 & 0,982 & 0,681 & 1,441 & 2,680 \\
\hline B71 & 1,165 & 0,782 & 1,489 & 3,237 \\
\hline B72 & 0,961 & 0,684 & 1,405 & 3,331 \\
\hline B73 & 0,754 & 0,562 & 1,342 & 3,195 \\
\hline B74 & 0,885 & 0,562 & 1,576 & 3,633 \\
\hline B75 & 0,907 & 0,601 & 1,509 & 3,396 \\
\hline B76 & 0,622 & 0,339 & 1,833 & 3,491 \\
\hline
\end{tabular}




\begin{tabular}{lllll} 
B77 & 1,115 & 0,731 & 1,524 & 3,521 \\
B78 & 1,090 & 0,737 & 1,478 & 3,408 \\
B79 & 0,985 & 0,689 & 1,430 & 3,047 \\
B80 & 1,010 & 0,710 & 1,423 & 3,473 \\
B81 & 0,904 & 0,589 & 1,536 & 3,391 \\
B82 & 1,091 & 0,720 & 1,515 & 3,450 \\
B83 & 0,962 & 0,726 & 1,325 & 2,675 \\
B84 & 1,087 & 0,652 & 1,666 & 3,485 \\
B85 & 1,207 & 0,683 & 1,768 & 3,781 \\
B86 & 1,137 & 0,755 & 1,506 & 3,296 \\
B87 & 0,989 & 0,656 & 1,508 & 3,485 \\
B88 & 1,148 & 0,794 & 1,445 & 3,355 \\
B89 & 1,076 & 0,761 & 1,414 & 2,988 \\
B90 & 1,011 & 0,751 & 1,347 & 3,030 \\
\hline
\end{tabular}

rgxsg = Index of reliability of item $\mathrm{g}$.

$\operatorname{rgX}=$ Correlation of item $g$ with total score

$\mathrm{sg}=$ Standard deviation of item $\mathrm{g}$.

$(\mathrm{g}=$ Mean of item $\mathrm{g}$

MEANS AND STANDARD DEVIATIONS OF ITEM STATISTICS

\begin{tabular}{lllll}
\hline & Mean of items & SD of items & $\mathbf{r}_{\mathrm{gx}}$ & $\mathbf{r}_{\mathrm{gx}} \mathbf{s}_{\mathrm{g}}$ \\
\hline \multicolumn{1}{c}{ Mean } & 3,415 & 1,523 & 0,640 & 0,972 \\
Standard Deviation & 0,475 & 0,111 & 0,094 & 0,145 \\
\hline & & & & \\
Cronbach alpha & $=$ & 0,982 & & \\
Number of items & $=$ & 84 & & \\
Mean of scale & $=$ & 286,876 & & \\
SD of scale & $=$ & 81,611 & &
\end{tabular}

From an inspection of Table 5 it is clear that all the items functioned very well and that not a single item was rejected. The reliability of the scale estimated by means of Cronbach's coefficient alpha is 0,982 , which is very high indeed. A single score of empowerment can therefore be used.

A secondary objective of the study was to determine whether or not there are group differences in terms of empowerment. Accordingly, groups were formed in terms of gender, age, language, length of service, academic qualification and remuneration.

Due to the fact that a single score was involved and that the number of groups varied from two to five, the differences were tested by means of Student's t-test (for two groups) and ANOVA, followed by Scheffé's post-hoc multiple comparisons, in the case of more than two groupings. Only the results in respect of gender and language proved to be statistically significant. The results of the t-test in respect of gender, are given in Table 6 .

\section{TABLE 6}

STUdent's T-TEST: CoMPARISON OF THE MEANS OF THE GENDER GROUPINGS IN RESPECT OF EMPOWERMENT

\begin{tabular}{lcccc}
\hline Variable & $\overline{\mathrm{X}}_{\boldsymbol{d}}$ & $\mathrm{t}$ & $\mathrm{df}$ & $\mathrm{p}$ \\
\hline Empowerment & 34,7750 & 2,640 & 147 & 0,009 \\
\hline
\end{tabular}

From an inspection of Table 6 it is clear that males perceive themselves as being more empowered than females, $\mathrm{t}(147)=$ 2,$640 ; p=0,009$.

From the ANOVA it is clear that the various language groups differ statistically significantly from one another, $F(2,143)=$ 9,930; $\mathrm{p}<0,001$. The results of the post- hoc multiple comparisons are given in Table 7.
TABLE 7

SCHEFFÉ's MULTIPLE COMPARISONS: COMPARISON OF THE MEANS OF THE VARIOUS LANGUAGE GROUPINGS IN RESPECT OF EMPOWERMENT

\begin{tabular}{lcccccc}
\hline \multicolumn{3}{c}{ Means of groups } & \multicolumn{3}{c}{ Groups } \\
\hline Variable & English (1) & Afrikaans(2) & African (3) & $1 / 2$ & $1 / 3$ & $2 / 3$ \\
Empowerment & 243,94 & 287,51 & 322,21 & $0,025^{*}$ & 0,081 * & 0,001 * \\
\hline * = Statistically significant & & & & &
\end{tabular}

* $=$ Statistically significant

From Table 7 it is clear that the English language grouping felt least empowered, compared to the Afrikaans and African language groupings. The African group felt most empowered.

\section{DISCUSSION}

Empowerment has been discussed and debated at great length, but not in respect of measurement. Perhaps this is due to the fact that no single, commonly understood and accepted definition of empowerment has been developed thus far.

The concept of empowerment relates to issues such as participation, involvement, communication etc., in organisations with the view to achieving a competitive advantage. However, no substantive research has been done on the development and validation of such a construct in order to allow organisations such as a local government institutions to determine employees' perceptions of empowerment. Establishing the perceptions of employees is a vital component in determining, evaluating and addressing areas of concern to the mutual benefit of the employee and the organisation.

The purpose of this study was to construct and evaluate a scale of employee empowerment that may assist organisational transformation.

The Employee Empowerment Questionnaire was constructed and yielded one scale with a reliability of 0,982 i.r.o. 84 items, according to Cronbach alpha. A single score of empowerment can therefore be used.

The results of this study indicate that the Employee Empowerment Questionnaire is highly reliable and sensitive to group differences. It appears that the mean item rating is 3,415 on a 7-point scale, which means that there is room for upward mobility in terms of empowerment.

A secondary objective of the study was to establish whether or not there are statistically significant differences in the means of various groupings formed in terms of gender, age, language, length of service, academic qualifications and remuneration with regard to empowerment. Gender and language yielded a statistically significant difference with regard to empowerment, whereas age, length of service, academic qualifications and remuneration did not.

It is clear that male employees perceive themselves as being more empowered than female employees and that the English language grouping felt least empowered in comparison to the Afrikaans and African language groupings. The African group felt most empowered.

It is evident from the results of the questionnaire that local government should concentrate its efforts (with regard to empowerment) on focusing and increasing the level of empowerment of female and English-speaking employees.

There may be limitations in the development of the questionnaire in the sense that other qualities might not have 
been incorporated, as the dimensions used were limited to those of Scott and Jaffe (1992), whose comprehensive list of empowerment dimensions suited the purpose of this study.

The study may have certain implications for employer and employees alike, which might be of value to the organisation as a whole. Schoeman (1990) claims that successful organisations concern themselves with empowerment and ensure that employees are given optimal opportunity to succeed. The employer can focus his attention on addressing empowerment imbalances in order to foster a climate conducive to empowerment, whilst employees will benefit from being empowered and knowing that they are contributing to and succeeding with the implementation of the broad vision of the organisation.

A number of additional research possibilities present themselves for further investigation, for example, the extent to which empowerment relates to other organisational variables, such as job satisfaction and intention to quit. An investigation of how employees perceive empowerment on different organisational levels, such as executive, managerial and supervisory levels would also be significant.

Since employees are obliged to seek and implement ways of improving their performance, use their skills and participate in the formulation of solutions, the main emphasis in the workplace should be on creating a climate of empowerment which is conducive to transforming an organisation such as local government into a highly involved, participative organisation.

\section{REFERENCES}

Barnes, N. R. (1990). Development of a measure of safety climate. Journal of Industrial Psychology, 16(1), 13-16.

Bekker, Q.E., \& Crous, F. (1998). Demystifying empowerment. Journal of Industrial Psychology, 24(2), 34-43.

Brown, R., \& Brown, M. (1994). Empowered: A practical guide to leadership in the liberated organisation. London: Nicholas Breasley.

Cook, J. (1993,October). The development cube: A model for staff empowerment. Paper presented at the Eight International Organisation Development Association World Conference entitled "Capacity Building in Developing Countries", Cape Town.

Cooks, S. (1993). Empowerment checklist. Empowerment in organisations: An International Journal, 1(3), 4-6.
Eccles, T.(1993). The deceptive allure of empowerment. Long Range Planning, 26(6), 13-21.

Exley, N. (1993). Building the empowered organisation. Empowerment in Organisations: An International Journal, 1(2), 4-9.

Gauteng (Province). Egoli 2000. Johannesburg: GJMC Printers, 2000.

Heil, G., Bennis, W., \& Stephens, D.C. (2000). Douglas McGregor, revisited: Managing the human side of enterprise. New York: John Wiley \& Sons.

Kaiser, H.F. (1961) A note on Guttman's lower bound for the number of common factors. British Journal of Statistical Psychology 14(1), 1.

Lepree, J. (1995). Building teams (employee empowerment boosts chemical industry productivity and customer satisfaction). Chemical Marketing Reporter, 247(4), 6-7.

Losey, M.R. (1995). The dawning of the high-performance workplace. Managing Office Technology, 40(3), 25-26.

Nixon, B. (1994). Developing an empowering culture in organisations. Empowerment in Organisations: An International Journal, 2(1), 14-24.

Payne, R.L. (1995). Organizational climate. In N. Nocholson. The Blackwell encyclopaedic dictionary of organizational behaviour. Oxford: Blackwell Business.

Payne, R.L., \& Mansefield, R. (1973). Relationships of perceptions of organizational climate to organizational structure, context and hierarchical position. Administrative Science Quarterly, $18,515-526$.

Potter, J. (1994). Tapping the iceberg. How to get the best of your people through empowerment. Empowerment in Organisations: An International Journal, 2(1), 4-8.

Robbins, S.P. (2001). Organizational behaviour, ( $9^{\text {th }}$ ed.). Upper Saddle River, NJ: Prentice-Hall.

Saal, F.E., \& Knight, P.A. (1988). Industrial/organizational psychology: Science and Practise. Belmont CA: Brooks/Cole.

Schoeman, J. (1990). Empowerment: a practical approach. IPM Journal, 11(90), 15-18.

Schreuder, A.M.G., \& Theron, A.L. (1997). Careers: An organisational perspective. Kenwyn: Juta \& Co.

Scott, C.D., \& Jaffe, D.T. (1992). Empowerment. Building a committed workforce. London: Kogan Page.

Semler, R. (1994). Maverick: The success story behind the world's most unusual workplace. London: Arrow.

Tustin, C.M. (1993). A consensus approach to the measurement of organisational climate. Journal of Industrial Psychology, 19(1), 1-4.

Woodman, R.W., \& King, D.C. (1997). Organizational climate: Science or folklore? Academy of Management Review, 3, 816-826. 